\title{
Factors Affecting Access to Formal Credit by Micro and Small Enterprises in Uganda
}

\author{
By Faisal Buyinza* \\ John Mutenyo \\ Anthony Tibaingana
}

\begin{abstract}
This article investigates the factors affecting access to formal credit by micro and small enterprises in Uganda using the Gender Enterprise Survey that was funded by the IDRC. The study employed a probit model. The findings show that firm sales, owner's education level, belonging to a business association, belonging to business group, use of internet, owning a personal and business bank account, and gender of the owner are positively associated with access to formal credit. We also find that experienced firms are less likely to apply for credit hence reduce the probability to receive formal bank credit. Our results provide insights on the existing gaps in designing supportive policies for micro and small enterprise to enable them increase their access to credit especially from the formal financial institutions.
\end{abstract}

Keywords: Credit constraint, micro and small enterprises, sample selection, Uganda.

\section{Introduction}

Micro and small enterprises (MSEs) form the backbone of most economies and they are a key source of economic growth, dynamism and flexibility in advanced and industrialized countries (Gunasekaran et al. 2011, World Bank 2008), as well as those that are emerging and developing like Uganda. Micro and small enterprises play a vital role in creating employment (Nikaido et al. 2015). Hence access to credit by these businesses can lead to high profit, wages and create more employment which significantly alleviates poverty (Sievers and Vandenberg 2007). Micro and small enterprises constitute the dominant form of business organisation accounting for over $95 \%$ and up to $99 \%$ of enterprises depending on the country. In Uganda, they constitute over 96\% (UBOS 2016). Organisation for Economic Cooperation and Development OECD (2006) notes that in OCED MSEs provide between $60-70 \%$ of net job creation and are important for bringing innovative products or techniques to the market.

Credit is an important component of a firm's survival and overall performance of the economy (Akoten et al. 2006, Yahya et al. 2012). Micro and small enterprises as drivers of economic growth provide a key building block for social economic change but are most vulnerable to external shocks due to their inherent limitation of access to credit among other factors. Consequently, more

\footnotetext{
${ }^{*}$ Senior Lecturer, Makerere University, Uganda.

${ }^{\dagger}$ Lecturer, Makerere University, Uganda.

Lecturer, Makerere University, Uganda.
} 
than half of the new ventures started in the developing countries are dissolved or stop operations annually (Mead and Liedholm 1998). Moreover government and its institutions are supposed to support firm's growth (Ngo and Chi 2017). Therefore limited access to credit constrains the economic development of these MSE's and hence requires a thorough analysis as this seems to be binding to many developing countries. Notably, micro and small enterprises in developing economies access credit from diverse sources ranging from relatives, friends, saving and credit organisations, micro-finance and commercial banks (Akoten et al. 2006). Micro and small enterprises access to credit and overall development of the economy and poverty reduction (Bhattacharjee and Rajeev 2010).

With onset of economic liberalisation in the early 1990s, the cost of credit has continued to be a major issue in the Ugandan economy (Bank of Uganda 2000, 2014). Thus, the Uganda government has continued to make various attempts to remedy this problem especially for MSEs. These attempts include low and or no interest schemes such as Entandikwa "Start-up Capital credit Scheme", Poverty Alleviation Programme, Rural Farmers Credit Scheme, and Bonna Baggagawale "Prosperity for all" Credit Scheme (Kasirye 2007, Mpuga 2008, Okum and Matovu 2006, Namatovu 2010, Tushabomwe-Kazooba 2006). Despite these efforts, supply of credit has continued to be a major concern that a bigger proportion of financial constrained entrepreneurs are left out (Owusu-Antwi 2010, Finscope 2010). The funding gaps relate to firm size, risk, knowledge, cost of credit, gender of the firm owner and flexibility. In addition, borrowing requirements of the micro firms are small yet more collateral may be required than they can pledge. On the side of financial institutions, they may lack expertise in understanding MSEs and flexibility in terms and conditions.

Uganda's financial sector is divided into four Tiers: The first Tier comprises commercial banks; the second include credit institutions and financial companies, while the third consists of the MDIs, and the fourth includes the SACCOS, Financial NGOs and all other non-deposit taking financial institutions (Bank of Uganda 2014). Tiers 1-3 are regulated and supervised by Bank of Uganda. However, financial inclusion in Uganda is still very low, with only $33 \%$ of the 12 million bankable population holding bank accounts besides a low saving-GDP ratio of $16 \%$. Interestingly, the stock of private sector credit to GDP stands at $11.8 \%$, an indicator of poor financial intermediation in the country. Formal institutions are less prominent in rural areas than urban areas; they only serve $14 \%$ of the rural population. However, the introduction of mobile money, the share of individuals operating a bank account has steadily increased, rising from $20 \%$ in 2011 to $44.4 \%$ in 2014 (Bank of Uganda 2015). Worse, access to formal financial institutions is unevenly distributed by district: $41 \%$ of districts in Uganda lack access to any bank branch, $41 \%$ and $48 \%$ of districts out of the 112 districts in Uganda lack access to any bank branch and ATM, respectively.

This article examines the enterprise level factors that affect access to formal credit for micro and small enterprises in Uganda using the Gender Enterprise Survey data ${ }^{1}$. In the Gender Enterprise Survey a micro enterprise was defined as a

\footnotetext{
${ }^{1}$ Gender and Enterprise survey 2015, was funded by the IDRC.
} 
firm employing between 1 to 4 paid non family workers and a small firm was defined as a business that employs between 5 and 20 paid non-family workers. The survey asked firm owners to provide information on several financial-related issues, growth and profitability of the firm, internal and external source of financing, credit applications and outcomes, cost of credit and availability. In addition, the survey collected rich information on the demographic and social characteristics and business environment. Based on a broad theoretical and empirical literature aimed at explaining MSEs access to credit, we focus on formal bank loans access granted to MSEs. Specifically, the critical issue addressed by this study is how the structure of the market as well as the social and institutional context, affect MSEs' access to formal credit. This implies that understanding the effect of factors per se on credit constraint is not enough; the differential effect on loan application and obtaining the loan can provide more meaningful insights.

Our findings not only contribute to the body of knowledge considering the changing socio-economic environment but also inform policy makers and the business community and other stakeholders on the effect of the structure of the financial market as well as the social and institutional factors on formal credit access by MSEs in Uganda in this era of globalisation. Significantly, we employ the sample selection probit model that is preferred in analysing SMEs access to formal credit because our interest focuses on the impact of covariates on actual loan received other than the mere overall factors that determine loan application when an application might be rejected. Exploring structure of the financial market as well as the social and institutional factors that affect MSEs access to firm credit opens up interesting avenues for public policy debate in developing countries like Uganda. Thus, understanding factors that influence MSEs' access to formal credit will provide a new and complementary lens for exploring MSEs access to formal credit and the study findings will be useful in devising policies to achieve the desired SMEs sector and its contribution to economic growth and development.

Section two reviews the selected literature on access to credit. The data and empirical strategy are described in section three. Section four presents and discusses the study findings, while the last section presents the concluding remarks.

\section{Literature Review}

There is large theoretical and empirical evidence on the determinants of MSEs access to formal credit (Chandler 2009, Grimm et al. 2015, Asiedu et al. 2012). Individual and business characteristics such as firm age, age, education, marital status, business association and saving culture, gender of owners, business location, use of ICT, and business diversification are key determinants of MSEs access to formal credit (Maksimov et al. 2017, Fatoki and Asah 2011, Cavalluzzo et al. 2002, Muravyev et al. 2009, Kira and He 2012, Honhyan 2009, Schubert and Leimstoll 2007). Evidence also shows that firm age, firm size, business diversity, owning bank accounts low education training (Klapper 2010, Ngoc et al. 2009, Kira and He 2012, Martinez-Solano 2014, Morewagae 
et al. 1995, Gimeno et al. 1997, Gilbert 2008) indicate positive effect on the probability of access to formal bank credit by MSEs.

Other factors that affect the likelihood of SMEs access to formal credit include high cost of credit, business networks, operation of personal and business bank accounts, lack of business records, collateral, poor loan screening, lack of accurate information about financial status of firms, age, lack of general skills management, lack of business plans and business records, poor banking and borrowing culture, and limited access to information on market opportunities (Navajas et al. 2003, Dabla-Norris and Koeda 2008, Fraser et al. 2013, Safavian and Wimpey 2007, Coleman 2009, Berger and Udell 1995, Degryse and Van Cayseele 2000, Sacerdoti 2005, Yahie 2000, Ajibade and Khayundi 2017, Fatoki et al. 2011, Hernández-Cánovas and Martínez-Solano 2010).

Abor and Biekpe (2009) note that firm age is an important determinant of SMEs' access to formal credit. The authors suggest that a firm that has been in operation for a long time, subsequently build a strong reputation over the years with the formal credit institutions, and hence can easily access formal credit. However, start-up firms are more likely to face financing problems and a firm's access to finance depends on its stage of development. Evidence by Fatoki and Asah (2011) reveal that SMES established more than five years have a far better chance to succeed in their loan applications compared with SMEs that have been in business less than five years.

Evidence shows that owner's characteristics make a difference to firms' ability and likelihood of accessing access formal credit (Irwin and Scott 2010, Cassar 2004, Mulaga 2013). That is, Vos et al., (2007) note that younger firm owners/managers tend to use more bank overdrafts and loans, credit cards, own savings, and family sources than old firm owners who appear to be more dependent on retained profits. In analysis of access to formal credit, Maksimov et al. (2017) found higher loan denial rates and lower loan application rates among female entrepreneurs. Also, evidence by Coleman (2007) show that there is credit discrimination against women firm owners/manager as they were frequently charged higher interest rates and asked to pledge additional collateral than their male counterparts in order to be granted loans. Evidence by Storey (1994) shows that higher levels of education provide entrepreneurs with greater confidence in dealing with bankers and other funders when applying for loans. Thus, education of the entrepreneur positively influence access to formal credit among SMEs. However, other studies find no impact of gender of owner and business location on MSEs access to formal credit (Zeller 1994). Also, there is mixed evidence with respect to prior business experience and firm size on access to formal credit (Frankish et al. 2012).

In analysis of the impact of firm characteristics on access to formal credit, Mabhungu et al. (2011) note that formality, value of assets, business sector, operating period, financial performance and size are all important factors in determining micro and small enterprises' access to finance. Financial institutions are more likely to approve loans to firms that are able to provide collateral and to those firms that have established long term relationships with lenders. Additional evidence by Anthony et al. (2013) and Odit and Gobardhum (2011) show that a 
firm's collateral security, and asset structure have a strong positive effect on the access to credit and the amount of loan received by firms. The authors conclude that SMEs with a lower tangible assets in their total assets are more likely to encounter difficulties in applying for formal credit because of the inability to provide collateral required by the financial institutions. Additional evidence shows that social capital influence in terms of credibility and trust affects access to credit (Alesiina et al. 2013, Guiso et al. 2013, Lozzi and Mistrulli 2014). No empirical study in Uganda has analysed structure of the financial market as well as the social and institutional factors at MSEs level on access to formal credit.

\section{Methodology}

Data

The empirical analysis is based on data drawn from the Gender and Enterprise Survey of 2015. The survey was a collaborative study conducted in three countries, Ghana, Kenya and Uganda funded by IDRC. For this survey, a twostage sampling design was utilized and the survey covered 1169 enterprises from 18 districts in nine sub-regions of the country. The survey used standardized survey instruments and a uniform sampling methodology to minimize measurement error and to yield data that are comparable with the National Surveys by Uganda Bureau of Statistics. The dataset covers the individual and firm characteristics of the Ugandan MSEs and the business environment. Specifically, in the survey, respondents provided answers which are particularly relevant in assessing the capability of MSEs to access and obtain formal credit. The survey posed a number of questions to the respondent: For instance, did you apply for a bank loan? What are the reasons for applying for the bank loan? What are the reasons why you did not apply? Did you get the loan? If yes, did you get the entire amount you applied for? If no, why were you denied the loan? Thus, one is able to identify whether the MSEs got credit or not, the sources of credit, amount applied for and amount received. In addition, the survey collected information on the socio-demographic factors such as gender of the owner, education level, firm age, business registration, ever got business training or not, urban or rural, business experience at start-up, sources of start-up capital among others. Our analysis draws on the credit history of the enterprise that has been in business for at least three years at the time of the survey to examine the factors that determine the Ugandan MSEs access to credit. The survey focused on enterprises that were in operation for at least three years before May 2015 and it covered only enterprises with trading activities at the time of the survey, implying that dormant enterprises were excluded. Thus, the data can be used to examine the determinants of enterprise start-up size and performance taking into account gender of the owner.

However, in spite of its importance, credit access by MSE's has not been adequately studied. This study extends the earlier works on factors that affect access to credit in Uganda by examining the effect of entrepreneur's education levels and firm size and firm performance and the different forms of credit 
constraint in Ugandan MSEs. Previous study in Uganda (Buyinza and Bbaale 2013, Okurut et al. 2005, Namatovu 2010) used ordinary least squares techniques and probit to estimate factors that affect credit constraints. This study improves on the previous work on Uganda by employing sample selection probit model. It is important to consider the issue of sample selection bias in this type of study, unless all MSEs included have a demand for formal credit. Whether MSEs can receive formal loans in the credit market depends on an individual firm's self-selection, that is, whether any given enterprise has a demand for credit. Generally, sample selection arises if unobservable factors such as owner's preference influence the selection process for the demand for formal credit and the subsequent application for the loan. Thus, we identify MSEs with formal credit demand as those enterprises that either reported that they had shortage of capital or did not have capital shortage but had received credit from a formal institution (Rand 2007, Bigsten et al. 2003). Therefore, MSEs that reported capital shortages are defined as "credit constrained enterprises" while the other category is defined as "credit unconstrained enterprises".

To analyse credit constraint among MSEs, a number of measures for credit constraints are constructed to provide more intuition of firms access to credit, we define the Non Credit Constrained (NCC) firms to include MSEs that did not apply for a loan in the year before the survey and have no outstanding loans and did not use external finances to finance start-up capital or investments. The main characteristic of this group of firms is that firms are happy with their current financing structure for both capital and investments. Second, the credit constrained firms are categorised into two-the Partially Credit Constrained firms (PCC) and the Fully Credit Constrained firms (FCC). The PCC includes firms that used external sources for their working capital and/or investments during the year before the survey and received the part of the whole amount of loan they applied for. On the other hand, the FCC firms that used external sources for their working capital and/or investments during the year before the survey but they applied for a loan and were rejected. So the Non-credit constrained (NCC) firms were coded as " 0 ", while Partially Credit Constrained (PCC) firms and Fully Credit Constrained (FCC) were coded as "1".

\section{Methodology}

To examine the determinants of access to formal credit in the context of Uganda's MSEs, we employ a probit model with sample selection, a two stage estimation process by Heckman $(1974,1979)$ for linear models and two stages probit by Van de Ven and Van Pragg (1981). The model assumes that the main outcome variable is observed only if a selection condition is satisfied. In this application, we use a binary dependent variable coded as " 1 " or " 0 " depending on whether a firm has access to formal credit or not. The binary probit is generally motivated by reference to latent (or unobservable) dependent variable (Lewis 1994, Skrondal and Rabe-Hesketh 2004) and usually expressed as a linear function of a set of explanatory variables as follows: 
1.

$$
y^{*}=\dot{x} \beta+u_{i}
$$

From Equation 1, $u_{i} \sim N\left(0, \sigma^{2}\right)$, $\mathrm{x}$ is a column vector of realizations of a set of $\mathrm{K}$ explanatory variables including a constant for firm $\mathrm{i}$ and $\beta$ is a column vector of $\mathrm{K}$ unknown parameters to be estimated. The values of the latent dependent variable are measured on the real line and in this study it reflects the underlying propensity of a given MSEs to have access to formal credit. The error term is assumed to be normally distributed with mean zero and constant variance. A threshold (assumed in this case) is used to delineate whether the firm has access to credit or not. Thus, the probability of an event occurring can be linked to the latent dependent variables as follows:

$$
\left[y_{i}^{*}>0\right]=P\left[y_{i}=1\right]=\Phi\left(z_{i}\right)
$$

From Equation 2, $y_{i}$ is the dichotomous realization of the latent dependent variable (and is either 'credit' or 'no credit' in this study. $\Phi$ denotes the cumulative distribution function operator for the standard normal distribution and $z_{i}=x \beta / \sigma$.

Given that $u_{1}$ and $u_{2}$ are normally distributed with mean zero and constant variance, if the $\operatorname{corr}\left(u_{1}, u_{2}\right)=\rho$ and $\rho \neq 0$, then estimation of Equation 1 will yield biased results (Lewis 1994, Skrondal and Rabe-Hesketh 2004). However, estimating Equation 1 using the probit model with a sample selection model will provides consistent and asymptotically efficient estimates for all of the parameters. In this model specification, we observe whether an enterprise in the sample demanded a formal loan in the credit market only if $y_{i}=1$ otherwise, for $y_{i}=0$ implies that the enterprise did not demand for any formal credit. Thus, in our selection Equation 2, we assume that an enterprise demanded for formal credit from the formal credit market. In Equation 2, the formal demand for credit is assumed to be affected by firm characteristics, business environment and the formalness of the enterprise in the sense that at least the firm employs paid workers other than family members. Therefore, the outcome of Equation 1, gives the status of the outcome of the loan application, that is, whether a firm received formal credit or not. To implement the empirical estimation, the dependent variable in Equation 1 takes the value "1" if an enterprise received formal credit and " 0 " otherwise.

For identification purposes it is conventional to normalise $\theta=1$. The $\log$ likelihood function is defined as:

3.

$$
L=\sum_{i=1}^{n} y_{i} \ln \left(\Phi\left(x^{\prime}\right)\right)+\left(1-y_{i}\right) \ln \left(1-\phi-\phi\left(x^{\circ} \beta\right)\right)
$$

The parameters are estimated using conventional nonlinear optimization algorithm. The efficient score tests suggested by (Heckman 1987) are undertaken to assess the reported specifications in terms of homoscedastic errors, and a 
normal distribution of the generalized residuals. In addition, the appropriate functional form and/or omitted variables are tested using RESET framework. The omitted variables or miss-specified functional form are proxied by the predicted standardised probit from the original probit regression model raised to the powers of two, three and four.

The estimated probit coefficients can be interpreted by reference to their effect on the standardized probit index but it is generally more convenient to translate them into marginal and impact effects. The marginal are denoted for continuous variables as denotes the probability distribution (or density) function for the standard normal distribution, $\beta_{k}$ is the estimated probit coefficient for the corresponding continuous variable, and $\mathrm{z}$ is the standardized probit index computed at the sample mean values of the characteristics. The impact effects are computed as where $\theta_{j}$ is the corresponding probit coefficient for the $j^{\text {th }}$ dummy variable, and the remainder is defined above. The asymptotic sampling variances for the marginal and impact effects are computed using the delta method.

From Equation 1, the dependent variable is the probability that an enterprise $i$ applies for a formal credit and, on conditional application, the probability of obtaining the formal credit is computed for the enterprise that received the loan defined by the outcome equation. We report the marginal effects for the second Hackman equation. The estimated marginal effects will show whether each independent variable causes either an increase of decrease in the likelihood of getting the loan on condition that a MSE applied for the loan, compared to the reference category.

\section{Results}

\section{Descriptive Results}

Figure 1 indicates the percentage distribution of MSEs by gender of owner that applied for formal credit and the various reasons advanced for the loan application. Overall, $76.7 \%$ of female and $63 \%$ of male MSEs applied for formal credit for business investment for example to buy more materials. The finding reveals existing demand for formal business credit in the country by MSEs. In addition, $10.7 \%$ of male and $4.5 \%$ of female MSEs reported to have applied for credit in order to purchase additional equipment tools. Figure 1 also shows that $8.3 \%$ of female and $6.5 \%$ of male MSEs had applied for credit to finance construction or hire of business premises, while $8.3 \%$ of male and female MSEs, respectively, applied for loans to meet family related expenses such as school fees. More so, $1.5 \%$ of female owned MSEs reported to have applied for loan to meet current business expenses compared to $3.7 \%$ of their male counterparts, while only $0.8 \%$ female owners reported to have applied for loans for land purchase compared to $7.9 \%$ of their male counterparts. 
Figure 1. Reasons Given by MSEs for Applying for Formal Bank Credit, Overall Sample (\%)

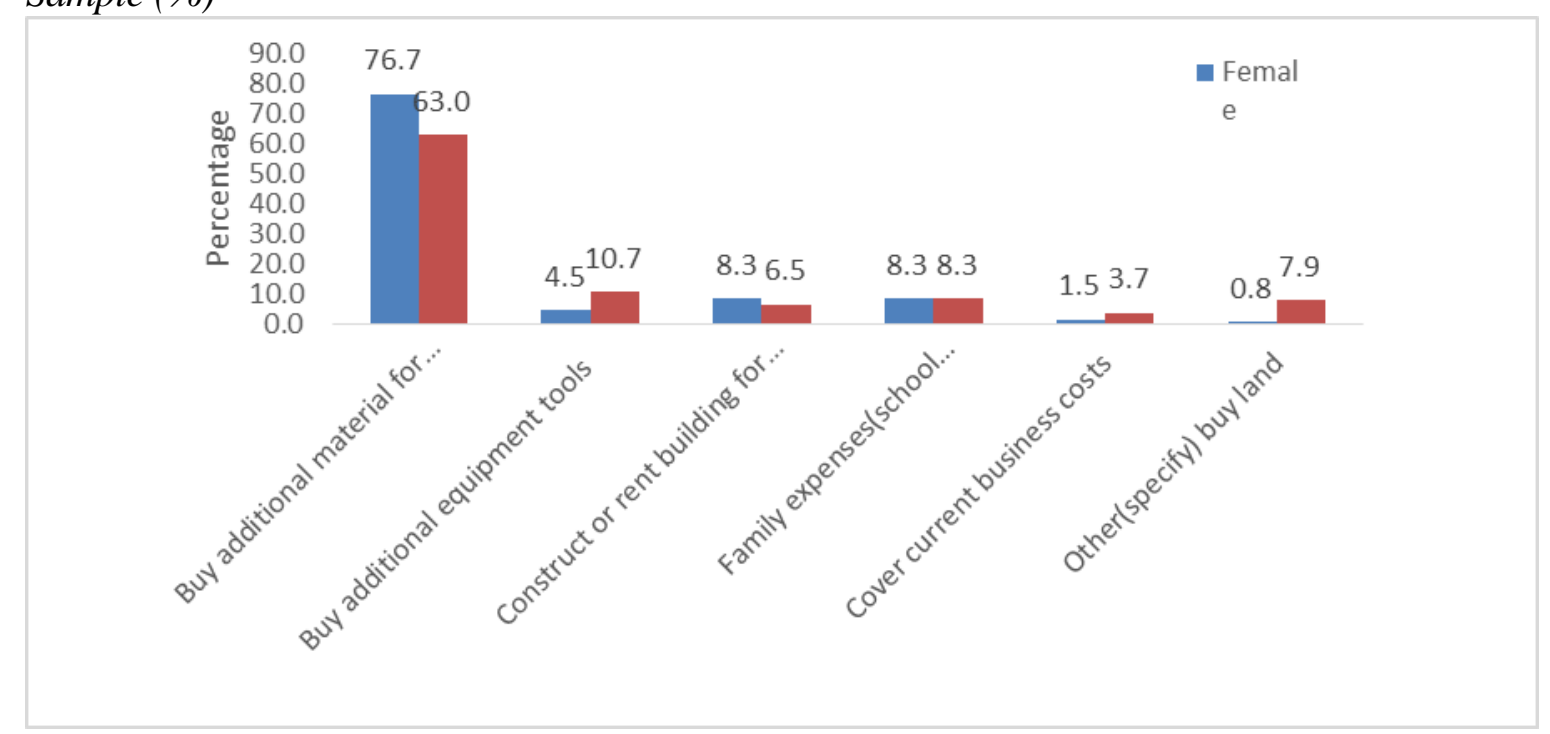

Source: Gender Enterprise Survey (IDRC, 2015)

Figure 2 presents credit constrained MSEs by gender that reported selfrestraint to apply for formal bank loans due to various reasons. As portrayed in Figure 2, about 55\% of female-owned MSEs reported not to apply due to fear of being in debts compared to $62 \%$ of their male counterparts. Also, $11.3 \%$ of female owned MSEs reported fear making payments compared to $6.9 \%$ of their male counterparts, while $9.8 \%$ female owners reported that interest rates are too high compared to $6.9 \%$ of their male counterparts. However, a lower percentage of $6.6 \%$ of female compared to $7.1 \%$ of male reported to prefer to save for future investments, while $6 \%$ and $2.2 \%$ of female and male respectively, preferred to borrowing from the spouse. Furthermore, $5 \%$ of female and $3.7 \%$ of male MSEs reported lack of collateral as a main restraint for applying for formal credit, while about $2.2 \%$ of male were deterred from loan application due to a demanding application process and $2 \%$ of female restrained to apply for formal credit due to fear of rejection.

Table 1 show that $30 \%$ of the total 1165 MSEs in the survey reported that they had a demand for credit, while only $24 \%$ reported that of those who applied for the credit did receive the loan, although some MSEs received less than what they desired. As the case for the credit constrained MSEs, 76\% who applied did not receive credit from any source, and we cannot identify whether they were denied credit. On average, firms where 10 years old and had relatively lower sales and employed very fear workers. In terms of gender composition, $65 \%$ of MSEs were owned by men. Interestingly, $19 \%$ of the MSEs owners hade postsecondary education, $49 \%$ had secondary education and $32 \%$ had primary. 
Figure 2. Reasons Given by MSEs for not applying for Formal Bank Credit by Gender (\%)

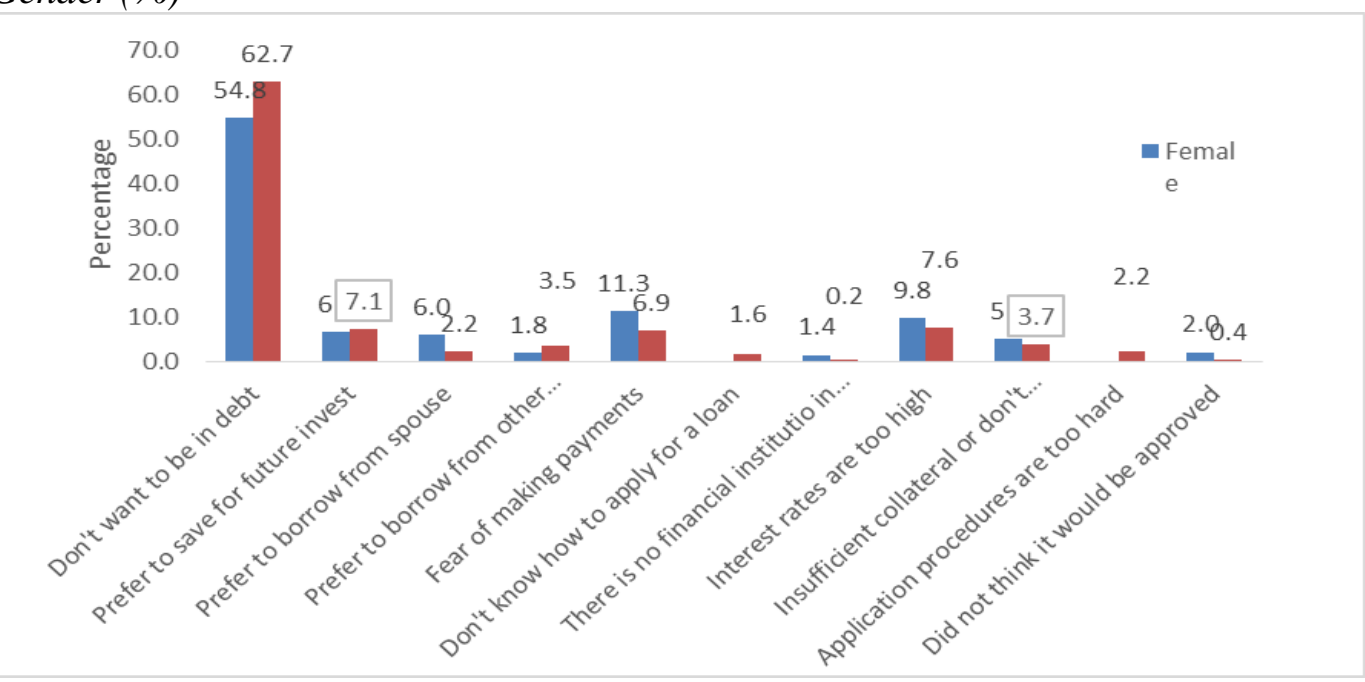

Source: Gender Enterprise Survey (IDRC, 2015)

In addition, $41 \%$ of MSEs use internet in form of emails and website for business, while only $9 \%$ use mobile money for business transactions. In terms of access to banks, we observe that $76 \%$ of MSE owners had personal bank account in contrast to only $25 \%$ of MSEs that operated a separate business bank account. Regarding business location $73 \%$ of MSEs reported to operate in hired premises, which is likely to constrain business in terms of hire operation costs. Also, as a form of networking, only $20 \%$ of MSEs are registered members of other business associations while 35\% MSEs have diversified business activities.

Table 1. Summary Statistics for the Study Variables

\begin{tabular}{|l|c|c|c|c|c|c|}
\hline Variable & $\mathrm{N}$ & mean & sd & cv & skewness & kurtosis \\
\hline Loan application & 1169 & 0.30 & 0.46 & 1.50 & 0.90 & 1.80 \\
\hline Received a loan & 1169 & 0.24 & 0.43 & 1.80 & 1.20 & 2.50 \\
\hline Firm age & 1166 & 10.00 & 8.20 & 0.79 & 2.20 & 9.50 \\
\hline sale & 1061 & 17.00 & 2.00 & 0.12 & -1.80 & 17.00 \\
\hline lbr & 616 & 12.00 & 1.40 & 0.11 & 0.24 & 4.40 \\
\hline Male owner & 1165 & 0.65 & 0.48 & 0.73 & -0.64 & 1.40 \\
\hline Primary education & 1164 & 0.32 & 0.47 & 1.50 & 0.79 & 1.60 \\
\hline Secondary education & 1164 & 0.49 & 0.50 & 1.00 & 0.04 & 1.00 \\
\hline Postsecondary education & 1164 & 0.19 & 0.40 & 2.00 & 1.50 & 3.40 \\
\hline Uses internet & 1146 & 0.42 & 0.34 & 0.18 & -1.80 & 6.30 \\
\hline Personal bank account & 1158 & 0.76 & 0.43 & 0.57 & -1.20 & 2.40 \\
\hline Business bank account & 1160 & 0.25 & 0.44 & 1.70 & 1.10 & 2.30 \\
\hline Mobile businesses & 1165 & 0.09 & 0.28 & 3.30 & 3.00 & 9.90 \\
\hline Business located at home & 1165 & 0.11 & 0.32 & 2.80 & 2.50 & 7.00 \\
\hline Business Hired place & 1165 & 0.73 & 0.45 & 0.61 & -1.00 & 2.00 \\
\hline Roadside business & 1165 & 0.08 & 0.27 & 3.50 & 3.20 & 11.00 \\
\hline Got training & 1153 & 0.32 & 0.47 & 1.50 & 0.76 & 1.60 \\
\hline Member of business group & 1151 & 0.20 & 0.40 & 2.00 & 1.50 & 3.20 \\
\hline Own other business & 1104 & 0.35 & 0.48 & 1.40 & 0.62 & 1.40 \\
\hline Exporter & 1147 & 0.12 & 0.33 & 2.70 & 2.30 & 6.30 \\
\hline
\end{tabular}

Source: Authors' calculation based on the Gender enterprise Survey (2015) 
Table 2. Comparison of Variables Means between Constrained/Fully Constrained and Unconstrained MSES

\begin{tabular}{|l|c|c|c|c|c|}
\hline Variables & $\begin{array}{c}\text { Unconstraine } \\
\mathrm{d}(\mathrm{N}=741)\end{array}$ & $\begin{array}{c}\text { Constrained } \\
(\mathrm{N}=320)\end{array}$ & Mean Diff & $\begin{array}{c}\text { Fully } \\
\text { constraine } \\
\mathrm{d}(\mathrm{N}=251)\end{array}$ & Mean Diff \\
\hline Firm age & 10.34 & 10.42 & -0.080 & 10.60 & -0.260 \\
\hline Log sale & 16.57 & 16.79 & -0.220 & 16.78 & -0.210 \\
\hline Log wages & 12.34 & 12.51 & -0.170 & 12.51 & -0.170 \\
\hline Male owner & 0.660 & 0.64 & 0.020 & 0.600 & $0.060^{* *}$ \\
\hline $\begin{array}{l}\text { Primary } \\
\text { education }\end{array}$ & 0.330 & 0.29 & 0.040 & 0.310 & 0.020 \\
\hline $\begin{array}{l}\text { Secondary } \\
\text { education }\end{array}$ & 0.500 & 0.46 & 0.040 & 0.450 & $0.050^{*}$ \\
\hline $\begin{array}{l}\text { Postsecondary } \\
\text { education }\end{array}$ & 0.170 & 0.25 & $-0.080^{* * *}$ & 0.240 & $-0.070^{* *}$ \\
\hline Use internet & 1.880 & 1.90 & -0.020 & 1.910 & $-0.030^{*}$ \\
\hline $\begin{array}{l}\text { Personal bank } \\
\text { Account }\end{array}$ & 0.700 & 0.90 & $-0.200^{* * *}$ & 0.910 & $-0.210^{* * *}$ \\
\hline $\begin{array}{l}\text { Firm Bank } \\
\text { Account }\end{array}$ & 0.220 & 0.33 & $0.110^{* * *}$ & 0.310 & $-0.090^{* *}$ \\
\hline $\begin{array}{l}\text { Mobile } \\
\text { businesses }\end{array}$ & 0.090 & 0.08 & 0.010 & 0.090 & 0.000 \\
\hline $\begin{array}{l}\text { Business } \\
\text { located at } \\
\text { home }\end{array}$ & 0.120 & 0.10 & 0.020 & 0.120 & -0.000 \\
\hline $\begin{array}{l}\text { Business } \\
\text { Hired place }\end{array}$ & 0.730 & 0.73 & 0.000 & 0.720 & 0.010 \\
\hline $\begin{array}{l}\text { Roadside } \\
\text { business }\end{array}$ & 0.070 & 0.08 & -0.01 & 0.080 & 0.000 \\
\hline Got training & 0.300 & 0.39 & $-0.090^{* * *}$ & 0.360 & $-0.060^{*}$ \\
\hline $\begin{array}{l}\text { Member of } \\
\text { business } \\
\text { group }\end{array}$ & 0.180 & 0.25 & $-0.070^{* * *}$ & 0.260 & $-0.080^{* * *}$ \\
\hline $\begin{array}{l}\text { Own other } \\
\text { business }\end{array}$ & 0.330 & 0.41 & $-0.080^{* * * *}$ & 0.400 & $-0.070^{* *}$ \\
\hline Exporter & 0.120 & 0.13 & -0.010 & 0.140 & -0.020 \\
\hline
\end{tabular}

$* * *$ Indicates that the difference between the means is greater than zero at the significance level of $1 \%$.

Source: Authors' calculation based on the Gender enterprise Survey (2015)

Table 2 presents sub-sample means for variables between constrained enterprises and unconstrained enterprises. In Table 2, we provide mean comparison test by controlling three groups, first unconstrained and constrained MSEs and then unconstrained and fully constrained MSES with the enterprises with credit demand employing a dummy variables (Constrained dummy) and (Fully constrained dummy). We find no difference between constrained MSEs, fully constrained and unconstrained MSEs in terms of sales, number of workers and firm age. However, the constrained MSEs are more likely to be owned by entrepreneurs with postsecondary education, they own a personal and business 
bank account. Also, owners of constrained MSEs are more likely to have got some business management and other related business training, members of some business associations and operate more than one business. In terms of the fully constrained MSEs, they are more likely to be owned by men, owners have secondary and postsecondary education. In addition, fully constrained MSEs are more likely to have participated in business management and other related business training, have both personal bank account and a separate bank accounted for the business. Furthermore, the fully constrained firms are significantly more likely to be a member of a business association, and have diversified business operations.

\section{Empirical Results}

Table 3 presents the marginal effects for the determinants of access to formal credit by SMEs in Uganda. The explanatory power of the models is rather strong. Overall, the Wald test of independent equations rejects the null hypothesis $\left(\mathrm{H}_{0}: \rho=0\right)$, validating the estimated model specification. Second, the Chi-square test for the estimated models could not be rejected that the selected variable are significant in explaining credit constraint and the F-test qualify the reliability of the estimated models. The estimation of one sample models (Table 3) for both male and female-owned MSEs is justified under the condition that the regression coefficients and variances are not different for the two groups of enterprises. Based on the poolability test, the F-test is performed based on the null hypothesis that male and female owned enterprises is the same for the two kinds of enterprises. The F-statistics derived from the regression is 1.88 , with a probability 87 and we could not reject the null at the conventional level of significance thus justifying the estimation of a combined regression.

First, results show that male owned MSEs are more likely to receive formal credit compared to their female counterparts. The estimated marginal effect for male ownership is positive and statistically significant at the conventional levels. The finding indicates that being male increases the probability of receiving formal credit by about $8 \%$ compared to their female counterparts. As indicated in the descriptive statistics, female owners fear having debts and therefore are likely to restrain from borrowing. As the literature indicates and our result are consistent with previous finding (Cavalluzzo et al. 2002, Muravyev et al. 2009) who find that female owned firms are less likely to apply for and/or receive formal bank credit compared to the male-owned firms.

In addition, the estimated linear and the quadratic effect of firm age as a measure of business experience have significant effect on the firm's access to formal credit. The results show that young MSEs with less experience in business are more ambitious and increases the likelihood of receiving formal credit, while old MSEs due the accumulated business experience and past lessons reduce the likelihood of receiving formal credit. The marginal effect on age of young firms shows that one year of entrepreneur's business experience increases probability of MSEs receiving formal credit by about $1 \%$, while the estimated quadratic age 
marginal effect shows that after certain age, one additional year of business experience would reduce receiving formal credit by between $30 \%$ and $32 \%$ because of self-financing firms reduce depending on external financing. Our findings contradict with evidence in the reviewed literature (Ngoc et al., 2009, Bougheas et al. 2005, Klapper 2010, Lore 2007) who find that young firms find difficulties in accessing bank financing due in large part to information asymmetry between banks and firms and young firms are more prone to failure than old firms.

Furthermore, as expected, the firm size measured by firm sales has a positive significant effect on the probability of receiving formal credit. The marginal effect shows that a unit increase in sales would increase the probability of receiving formal credit by $1 \%$. This result shows the importance of firm performance and what formal financial institutions value when assessing the credit worthiness of a loan applicant. This finding indicates that even within small enterprises, size does matter as far as credit access is concerned. This finding is in line with previous authors (Martinez-Solano 2014, Kira and He 2012) who note that firm sales are a key determinant of a firm's access to credit. Therefore, there is need for measures aimed at promoting market access to enable MSEs to grow their sales.

Also, findings show that use of mobile money for business has a significant positive effect on access to formal credit. Although mobile money use is an informal sector activities but it has a significant effect on overall access to formal credit. The results show that firms using mobile money for business have a higher chance of about $6 \%$ of getting formal credit compared to their counterparts who do not uses mobile money. This finding has strong implication in terms of government policy for financial inclusion and access by all people in the country.

Interestingly, the study finds that use of information technology in business operations by MSEs has a positive and significant effect on the probability of receiving formal credit. The marginal effect shows that MSEs using information technology in terms of emails, website and social media increases the probability of receiving formal credit by between $8 \%$ and $10 \%$ compared to their none-users counterparts. This finding reveals the potential growth of spatial business dealings by MSEs that firms can advertise their goods on their websites, Facebook among others at a low or no cost and also because of access to information via internet, they are more acquitted with what financial institutions require for loans disbursements. This finding is in line with the reviewed studies (Buyinza and Bbaale, 2013, Dixon et al. 2002) who concluded that growth of ICT has the potential of promoting inclusive banking of the un-bankable communities.

Also, the results show that MSEs that operates from hired commercial places have a significant positive effect on the probability of receiving formal credit. The estimated marginal effect indicates that an urban based MSEs has a probability of $5 \%$ of receiving formal credit compared to counterpart operate from home. The main explanation of this is that commercially MSEs have a greater access to financial institutions and in the case of Uganda over $80 \%$ of the banking industry is urban based (UBOS 2017), which give them a higher opportunity to access formal credit than their home based MSEs counterparts. This finding is in line with previous studies (Fatoki and Smit 2011; Buyinza and Bbaale 2013) who find that firms located in urban areas have a high probability of accessing bank finance than 
Vol. 4, No. 4 Buyinza et al.: Factors Affecting Access to Formal Credit by Micro...

their rural counterparts due to exposure in urban areas that provide advantage of information to urban business operators to get credit.

Table 3. Estimated Marginal Effect for Access to Credit by Mses in Uganda

\begin{tabular}{|c|c|c|c|c|}
\hline & Model 1 & & Model 1 & \\
\hline Variables & $\begin{array}{c}\text { Marginal } \\
\text { effects }\end{array}$ & & $\begin{array}{c}\text { Marginal } \\
\text { effects }\end{array}$ & \\
\hline Male owner & & & $0.0842 * * *$ & $(0.000)$ \\
\hline Firm age & $0.012 * * *$ & $(0.000)$ & $0.010^{*}$ & $(0.065)$ \\
\hline Firm age squared & $-0.322 * *$ & $(0.054)$ & $-0.291 * *$ & $(0.048)$ \\
\hline Log firm sales & 0.006 & $(0.593)$ & $0.010^{*}$ & $(0.075)$ \\
\hline Uses mobile money & $0.055^{* *}$ & $(0.026)$ & & \\
\hline Uses internet & $0.0825^{*}$ & $(0.063)$ & $0.102 * * *$ & $(0.001)$ \\
\hline \multicolumn{5}{|c|}{ Business location (RC: Mobile) } \\
\hline Business located at home & & & -0.041 & $(0.524)$ \\
\hline Business location hired & & & $0.0531 * *$ & $(0.046)$ \\
\hline Business located at road side & & & -0.011 & $(0.640)$ \\
\hline Member of business group & & & $0.015 * *$ & $(0.033)$ \\
\hline Received business training & $0.042^{* *}$ & $(0.028)$ & $0.012 *$ & $(0.061)$ \\
\hline Employs hired workers & 0.003 & $(0.751)$ & $0.068^{*}$ & $(0.057)$ \\
\hline \multicolumn{5}{|l|}{ Region (RC: Central) } \\
\hline Eastern & & & $-0.091 * * *$ & $(0.000)$ \\
\hline Northern & & & 0.040 & $(0.445)$ \\
\hline Western & & & $0.157 * * *$ & $(0.004)$ \\
\hline Own business bank account & $0.025 * *$ & $(0.033)$ & 0.032 & $(0.339)$ \\
\hline Personal bank account & $0.195 * * *$ & $(0.000)$ & $0.204 * * *$ & $(0.000)$ \\
\hline Own other businesses & $0.0622 * *$ & $(0.030)$ & $0.065^{*}$ & $(0.072)$ \\
\hline \multicolumn{5}{|l|}{ Education (RC: Primary) } \\
\hline Secondary & & & -0.028 & $(0.0308)$ \\
\hline Postsecondary & & & $0.022 * *$ & $(0.043)$ \\
\hline Formally registered & 0.003 & $(0.138)$ & -0.001 & $(0.0317)$ \\
\hline Owned business before & -0.001 & $(0.294)$ & 0.005 & $(0.0326)$ \\
\hline \multicolumn{5}{|c|}{ Start decision (RC: Non family members) } \\
\hline Alone & $0.102 * *$ & $(0.0495)$ & & \\
\hline Spouse & $0.203 * * *$ & $(0.0748)$ & & \\
\hline Family member & 0.114 & $(0.0696)$ & & \\
\hline $\begin{array}{l}\text { LR test of independent. } \\
\text { eqns. }(\text { rho }=0): \mathrm{Chi}^{2}(1)\end{array}$ & 10.74 & $(0.000)$ & 8.23 & $(0.001)$ \\
\hline Wald chi2 & 24.00 & $(0.008)$ & 16.72 & $(0.000)$ \\
\hline Log likelihood ratio & 487.71 & & 450.14 & \\
\hline Observations & 955 & & 923 & \\
\hline Censored observation & 726 & & 713 & \\
\hline Uncensored & 220 & & 210 & \\
\hline
\end{tabular}

Note: $\mathrm{P}$-values in parenthesis $* \mathrm{p}<0.05, * * \mathrm{p}<0.01, * * * \mathrm{p}<0.001$.

Source: Author. 
In addition, being a member of a business group has a significant effect on access to form credit by MSES. The estimated model reveals that SMEs that are member of some business group of are about $2 \%$ more likely to get formal credit that their counterparts that are non-members. Also, having received training in business management significantly increase the probability of receiving formal credit among Ugandan MSEs. The estimated marginal effects indicate that MSE owners who received training are between $4 \%$ and $1 \%$ likely to receive formal credit compared to their non-trained counterparts. This finding indicates that exposure to business information, business management, record keeping, market information, loan application procedures and requirements among others is key to formal credit access. Worth to note, the results show that MSES that employ hire wage workers are more likely to access formal credit than counterparts that do not hire paid workers.

As expected owning a personal bank account and a separate business bank account have a significantly positive impact on the probability of receiving formal credit among MSEs in Uganda. The results reveal that a firm owner owning a personal bank account increases the probability of receiving a formal credit by $3 \%$ compared to counterpart MSEs with no personal bank accounts. Also, an MSE having a firm bank account increases the probability of receiving forma bank credit by about $20 \%$ compared to an MSE with no business bank account. This finding is in line with previous studies (Fatoki and Smit 2011) who document the importance of having bank accounts as one of the determinants of access to credit.

Also, the study results show that business diversification practices have a significant positive effect on the probability of receiving formal credit among MSEs in Uganda. The results show that an MSE with diversified business operation significantly increases the probability of receiving formal credit by between $6 \%$ and $7 \%$ compared to counterparts having only one business. In other words, entrepreneurs having more than one business tend to be more rigorous in looking for formal financing compared to their counterpart running only one business. This finding means that business diversification makes MSEs more resilient to economic downturns, and thus, those that are engaged in more diversified activities can be expected to be more profitable and creditworthy to the financial institutions. This finding is in line with previous studies who note that diversification increases creditworthiness of the borrower and ability of loan repayment.

Interestingly, the effect of regional location on MSEs' access to credit show that MSES located in the Eastern have a likelihood of $9 \%$ of not access to formal credit compared to counterpart located in the Central region, while MSES located in the Western region are $16 \%$ likely to access formal credit compared to counterparts located in the Central region.

As documented in the reviewed studies (Kira and He 2012, Muravyev et al. 2009) education level of the firm owner significantly increases the probability of access to formal credit among MSEs in Uganda. The marginal effect shows that an entrepreneurs having post-secondary education increase the probability of receiving formal credit by $2 \%$ compared to counterparts with primary education. This result shows the importance of education in general as it equips potential 
entrepreneurs with literacy that they are trainable and can manage business on their own because they are able to do business record keeping. Besides, level of education empowers individuals with financial literacy and this enables them to process loan application with formal financial institutions. Therefore, there is need for measures aimed at promoting education as per the government's USE and UPE programs.

\section{Concluding Remarks}

The study employed a sample selection probit model to address the sample selection bias that commonly affect empirical results with survey-based data to investigate enterprise level factors affecting MSEs access to formal credit in Uganda using the Uganda Gender Enterprise Survey data (IDRC, 2015). The results show that gender of the owner, firm's business experience, firm size and firm's location, use of mobile money and information technology have a significant positive impact on the probability of receiving formal credit. Also, enterprises with diversified business operations are more likely to receive formal credit followed by MSEs with personal and business bank accounts that implicitly have good relationship with banks. Not surprisingly, the study also find that very experienced firms are less likely to receive formal bank credit. These results are in line with the reviewed literature on credit constraints by MSEs. Overall, it can be concluded that firm size do matter among MSEs and sex of the owner regarding a better chance of receiving formal credit.

Our findings suggest that government and other shareholders should put in place necessary measures for corrective intervention regarding promotion of marketing and financial inclusion for women enterprises and equal urban-rural development. Second, very specific and intense training programs are needed for the MSEs to impart knowledge and skills to the owners on business and management. There is need for established information centers in the country where MSEs can obtain support in terms of business management education and technical training, consultancy, marketing approaches, market information, common facilities and promotion of activities which aim at exposing their products and enterprises network, relationships and connection in the country. Also, measures aimed at encouraging entrepreneurs to get ICT training should be undertaken in order to access to business information and services is a potential source of gainful access to formal credit.

\section{References}

Abor J, Biekpe N (2009) How do we explain the capital structure of SMEs in Sub-Sharan Africa. Journal of Economic Studies 36(1): 83-97.

Ajibade P, Khayundi FE (2017) The Role of Records Management in Small Micro and Medium Enterprises (SMMEs) in South Africa and Its Implications for Business Sustainability. African Journal of Library, Archives and Information Science 27(2). 
Akoten JE, Sawada Y, Otsuka K (2006) The determinants of credit access and its impacts on micro and small enterprises: The case of garment producers in Kenya. Economic development and cultural change 54(4): 927-944.

Alesiina A, Lotti F, Mistrulli P (2013) Do women pay more for credit? Evidence from Italy. Journal of European Economic Association 11: 45-66.

Anthony KA, Frank GS (2013) Determinants of credit rationing to the private sector in Ghana. Journal of Business management 7(38): 3864-3874, 14.

Asiedu E, Freeman J, Nti-Addae A (2012) Access to credit by small businesses: How relevant are race, ethnicity, and gender? American Economic Review 102: 532-537.

Bank of Uganda (2000) Market needs assessment for rural financial services in selected districts of Uganda. Kampala.Development Finance Department.

Bank of Uganda (2014) Status of Financial Inclusion in Uganda. Kampala Uganda.

Bank of Uganda (2015) Financial Stability Report June 2015 7. Kampala Uganda.

Berger A, Udell G (2006) A more conceptual framework for SME financing. Journal of Banking and Finance 30(11): 2945-2966

Berger AN, Udell GF (1995) Relationship Lending and Lines of Credit in Small Firm Finance. The Journal of Business 68(3): 351-381.

Bhattacharjee M, Rajeev M (2010 September) Interest rate formation in informal credit markets in India: does level of development matter? BWPI Working Paper 126: 1-27.

Bigsten A, Collier P, Dercon S, Fafchamps M, Gauthier B, Grunning JW, Zeufack A (2003) Credit Constraints in Manufacturing Enterprises in Africa. Journal of African Economies 12(1):104-125.

Bougheas S, Mizen P, Yalcin C (2005) Access to external finance: Theory and evidence on the impact of monetary policy and firm-specific characteristics. Journal of Banking \& Finance 30(1): 199-227.

Buyinza F, Bbaale E (2013) Access to Credit and the Effect of Credit Constraints on the Performance of Manufacturing Firms in the East African Region: Micro Analysis. International Journal of Economics and Finance 5(10): 1916-9728. 2013 ISSN 1916971X E-ISSN.

Cassar G (2004) The Financing of Business Start-Ups. Journal of Business Venturing. 19(2): 261-283.

Chandler JG (2009) Marketing tactics of selected small firms in the east London cbd area. South Africa: University of South Africa.

Coleman S (2007) The Role of Human and Financial capital in the Profitability and Growth of Women-Owned Small Firms. Journal of Small Business Management 45(3): 303-319.

Coleman S, Robb A (2009) Comparison of new firm financing by gender: evidence from Kauffman Firm Survey data. Small Business Economies 33(4): 397-411.

Cavalluzzo K, Cavalluzo L, Wolken J (2002) Competition, small business financing, and discrimination: Evidence from a new survey. Journal of Business 75: 641-680.

Dabla NE, Koeda J (2008) Informality and bank credit: evidence from firm level data. Monetary Fund, Middle East and Central Asian Department.

Degryse H, Van Cayseele P (2000) Relationship Lending within a Bank-Based System: Evidence from European Small Business Data. Journal of Financial Intermediation 9(1): 90-109.

Dixon T, Thompson R, McAllister P (2002) The Value of ICT for SMEs in the UK: A Critical Literature Review. College of Estate Management, Reading.

Fatoki O, Smit AVA (2011) Constraints to credit access by new SMEs in South Africa: A supply-side analysis. African Journal of Business Management 5(4): 1413. 
Fatoki O, Asah F (2011) The Impact of Firm and Entrepreneurial Characteristics on Access to Debt Finance by SMEs in King Williams's Town, South Africa. International Journal of Business and Management 6(8): 170-179.

FinScope (2010) FinScope Uganda 2009: Results of a National Survey on Demand, Usage and Access to Financial Services in Uganda. Uganda: DFID Steadman Synovate.

Frankish JS, Roberts RG, Coad A, Spears TC, Storey DJ (2013) Do entrepreneurs really learn? Or do they just tell us that they do? Industrial and Corporate Change 22(1): 73-106.

Fraser S, Buhaumik S, Wright M (2013) What do we Know about the Relationship Between Entrepreneurial Finance and Growth? UK: Enterprise Research Center (ERC).

Gimeno J, Folta T, Cooper A, Woo C (1997) Survival of the Fittest? Entrepreneurial Human Capital and the Persistence of Underperforming Firms. Administrative Science Quarterly 42(4): 750-83.

Guiso L, Sapienza P, Zingales L (2013) The Determinants of Attitudes Towards Strategic Default on Mortgages. Journal of Finance 68(4): 1473-1515.

Gunasekaran A, Rai BK, Griffin M (2011) Resilience and competitiveness of small and medium size enterprises: an empirical research. International journal of production research 49(18): 5489-5509.

Gilbert BA (2008) New venture performance: does location matter. Retrieved from https://bit.ly/2N5eLit.

Grimm M, Paffhausen AL (2015) Do interventions targeted at micro-entrepreneurs and small and medium-sized firms create jobs? A systematic review of the evidence for low and middle income countries. Labour Econ 32: 67-85.

Heckman JJ (1974) The common structure of statistical models of truncation, sample selection and limited dependent variable and simple estimator for such models. Annals of Economic and Social Measurement 5: 475-492.

Heckman JJ (1979) Sample selection bias as a specification error. Economtrica 47(1): 153-161.

Heckman JJ (1987) Selection bias and self-selection. In Eatwell J, Milgate M, Newmann P (eds), The New Palgrave, 287- 297. New York: Stockton.

Irwin D, Scott JM (2010) Barriers Faced by SMEs in Raising Bank Finance. International Journal of Entrepreneurial Behaviour and Research 6(3): 245-259.

Lewis HG (1974) Comments on selectivity biases in wage comparisons. Journal of Political Economy 82: 1145-1155.

Lore M (2007) An Evaluation of Human Capital Factors that can Enhance Access to Credit among Retailers in Nairobi. Unpublished thesis submitted to United states International University-Africa. Nairobi.

Hernández-Cánovas G, Martínez-Solano P (2010) Relationship lending and SME financing in the continental European bank-based system. Small Business Economics 34(4): 465-482.

Honhyan Y (2009) The Determinants of Capital Structure of the SMEs: An Empirical Study of Chinese listed Manufacturing Companies. Manufacturing Companies. Retrieved from https://bit.ly/2LbSkq6.

Kasirye I (2007) Rural Credit Markets in Uganda: Evidence from the 2005/6 National Household Survey. Retrieved from https://bit.ly/2MHi9CY [Accessed 5 April 2013].

Kira AR, He Z (2012) The Impact of Firm characteristics in Access of Financing by Small and Medium sized Enterprises in Tanzania. International Journal of Business and Management 7(24): 108-186. 
Klapper L, Laeven L, Rajan R (2010) Entry regulation as a barrier to entrepreneurship. Journal of Financial Economics 82(3): 591-623.

Lozzi M, Mistrulli PE (2014) Loan Applications and Social Capital in the Great Recession. Bank of Italy, mimeo.

Mabhungu I, Masamha B, Mhazo S, Jaravaza D, Chiriseri L (2011) Factors influencing micro and small enterprises' access to finance since the adoption of multi-currency system in Zimbabwe. Journal of Business Management and Economics 2(6): 217222.

Morewagae BS, Seemule M, Rempel H (1995) Access to credit for none-formal microenterprises in Botswana. The Journal of Development Studies 31(3): 481-504.

Okumu L. and Matovu, J. (2006) Credit Accessibility to the Rural Poor in Uganda, EPRC Research Series No. 1 .

Maksimov V, Wang SL, Luo Y (2017) Reducing poverty in the least developed countries: The role of small and medium enterprises. Journal of World Business 52(2): 244-257.

Martinez Peria MS, Singh S (2014) The impact of credit information sharing reforms on firm financing. World Bank Policy Research Working Paper, 7013.

Mead DC, Liedholm C (1998) The dynamics of micro and small enterprises in developing countries. World development 26(1): 61-74.

Mpuga P (2008) Constraints in access to and demand for rural credit: evidence from Uganda. Retrieved from https://bit.ly/2nUFQtP. [Accessed 10 June 2013].

Mulaga AN (2013) Analysis of External Financing Use: A Study of Small and Medium Enterprises in Malawi. International Journal of Business and Management 8(7):5564.

Muravyev A, Talavera O, SchÃfer D (2009) Entrepreneurs gender and financial constraints: Evidence from international data. Journal of Comparative Economics 37(2): 270-286.

Navajas S, Conning J, Gonzalez-vega C (2003) Lending technologies, competition and consolidation in the market for microfinance in Bolivia. Journal of International Development 15: 747-770.

Namatovu R, Balunywa W, Kyejjusa S, Dawa S (2010) Global Entrepreneurship Monitor Uganda Executive Report.

Nikaido Y, Pais J, Sarma M (2015) What hinders and what enhances small enterprises' access to formal credit in India? Review of Development Finance 5(1): 43-52.

Ngo CN, Chi M (2017) Differentials in market constraints and value addition among micro, small, and medium enterprises in Viet Nam. World Institute for Development Economic Research 82.

Ngoc TB, Le T, Nguyen TB (2009) The impact of networking on bank financing: The case of small and medium enterprises in Vietnam. Entrepreneurship Theory and Practice 33(4): 867-887.

Odit MP, Gobardhun YD (2011) The Determinants of Financial Leverage of SME's in Mauritius. The International Business and Economics Research Journal 10(3): 113.

Okurut N, Schoombee A, Van der Berg S (2005) Credit demand and credit rationing in the informal Financial Sector in Uganda. South African Journal of Economics 73(3): 1-9.

Organisation for Economic Cooperation and Development (2006) The SME Financing Gap (1) Theory and Evidence OECD.

Owusu-Antwi G, Antwi J (2010) The Analysis of the rural credit market in Ghana. International Business \& Economics Research Journal 9(8): 45-56.

Rand J (2007) Credit constraint and determinants of the cost of capital in Vietnamese Manufacturing. Small Bus.Econ 29(1-2): 1-13.

Sacerdoti E (2005 August) Access to Bank Credit in Sub-Saharan Africa: Key issues and Reforms Strategies. International Monetary Fund (IMF) Working Paper WP/05/166 
Schubert P, Leimstoll U (2007) Importance and Use of Information Technology in Small and Medium-Sized Companies. Electronic Markets 17: 38-55.

Safavian M, Wimpey J (2007) When Do Enterprises Prefer Informal Credit. World Bank Policy Research Working Paper Series 4435.

Sievers M, Vandenberg P (2007) Synergies through linkages: Who benefits from linking micro-finance and business development services. World Development 35(8): 13411358.

Skrondal A, Rabe-Hesketh S (2004) Genralized Latent Variable Modeling: Multilevel, Longitudinal, and Structural Equation Models. Boca Raton, FL: Chapman \& Hall/CRC.

Tushabomwe-Kazooba C (2006) Causes of Small Business Failure in Uganda: A Case Study from Bushenyi and Mbarara Towns. African Studies Quarterly 8(4):9.

Uganda Gender Enterprise Survey (2015) African gender Enterprise Survey for the IDR. Uganda.

Van de Ven WPMM and Van Pragg BMS (1981) The demand for deductibles in private health insurance: A probit model with sample selection. Journal of Econometrics 17(2): 229-252.

Vos E, Yeh AJ, Carter S, Tagg S (2007) The Happy Story of Small Business Financing. Journal of Banking and Finance 31(9): 2648-2672.

World Bank (2008) Finance for All: Policies and Pitfalls in Expanding Access. WorldBank Policy Research Report.

Williams WS (2006 March) Supporting the Growth of Small and Medium Enterprises. Address to the Nova Committee of the Trinidad and Tobago Chamber of Industry and Commerce. Retrieved from https://bit.ly/2MDFBRF.

Yahie AM (2000) Poverty reduction in sub-Saharan Africa: Is there a Role for private sector? African Development Bank Economic Research Paper 52.

Yahya A, Othman MS, Shamsuri ALS (2012) The Impact of Training on Small and Medium Enterprises (SMEs) performance. Journal of Professional Management 2(1): $15-25$.

Zeller M (1994) Determinants of Credit rationing: A study of informal lenders and formal credit groups. 